\title{
Gjens var
}

til

Hr. Regjeringsassessor P. v. Hedemann.

Af Henning Matzen.

I „Zeitschrift der Gesellschaft für SchleswigHolsteinische Geschichte" 34ster Band S. 230-235 har Hr. Regjeringsassessor P. v. Hedemann gjort et Afsnit af min Bog "Die nordschleswigsche Optantenfrage" til Gjenstand for en længere Kritik, som indledes med en Bemærkning om, at Oversættelses- og Trykfejl have vanskeliggjort Bogens Læsning. Jeg kan kun paaskjonne, at disse Vanskeligheder dog ikke have afholdt den ærede Kritiker fra at gjore det paagjældende Afsnit af Bogen til Gjenstand for et indgaaende Studium; thi hans urbane Udtryksmaade og saglige Behandling gjor det til en Fornøjelse for mig at optage en Droftelse af Amnet med ham.

Det Afsnit af Bogen, som Kritiken omhandler, er det forste, angaaende Optanternes Indfedsret 5.8 flg.

Som bekjendt indrommer Fredstraktaten 30. Okt. 1864 Art. XIX. forst de paa de afstaaede Territorier 
bosatte Undersaatter en Optionsret med Hensyn til, om de fremtidig ville være Undersaatter under den nye Regjering i Hertugdommerne eller vedblive at rære danske Indersaatter. Derefter tilfojer den i 5te Stykke, at Indfodsretten. „le droit d'indigénat", som den kaldes i Traktatens originale franske Text, bevares for alle, som den 16de Novbr. 1864 vare i Besiddelse af den, baade i Kongeriget og i Hertugdømmerne.

Forfatteren fremhæver S. 230, at den sidstnævinto Bestemmelse allerede faa Aar derefter - nemlig i Aaret 1873 under Forhandlingerne om den i dansk Bekjgj. 19. December 1873 kundgjorte Overenskomst om trængende Undersaatters Hjemsendelse fra det ene Rige til det andet - blev Gjenstand for en modstridende Fortolkning henholdsvis fra dansk og tysk Side i Henseende til Forstaaelsen af Udtrykket Indfødsret. Denne Paastand er dog ikke ganske korrekt formuleret. Som i min Bog S. 47-49 dokumenteret, stillede Sagen sig i Virkeligheden saaledes, at den preussiske Regjering simpelthen benægtede de danske Optanters Indfodsret i Hertugdommerne eller - efter disses Indlemmelse ved Lov 24. December 1866 - i Preussen, illet den yik ud fra, at Valg af Undersaatsforboldet tillige betod Valg af Indfodsret (Indigenat), og at altsaa de Indfodte, der havde valgt dansk Undersaatsforhold, ved selve dette Valg havde opgivet deres Indfodsret i Preussen, en Paastand, som endnu f. Ex. „Kölnische Zeitung" for ikke lienge siden har gjon. taget. 
Naar Forfatteren hertil yderligere føjer, at den danske Regjering ikke ved den Lejlighed ses at have folt sig sikker nok til at yde den preussiske Regjering et fyldestgjorende Bevis for sin Fortolknings Rigtighed eller endog blot at have gjort et Forsog derpaa, saa er denne Bemærkning egnet til at fremkalde den Misforstaaelse, at den danske Regjering ved samme Lejlighed skulde have frafaldet sin Fortolkning. Men at dette ikke var Tilfældet, har jeg dokumenteret $i$ min Bog S. 49-50, hvor jeg har paarist, at den danske Regjering klarede Tanskelighederne og forte Forhandlingerne om Orerenskomston til en lykkelig Udgang ved at foreslaa en Affattelse af den omtvistede Art. 5 vedrorende Optanternes Forsorgelsesret, som aldeles ikke berørte Sporgsmaalet om deres Indfødsret.

Ilen denne Strid angaaende Sporgsmaalet, om Optanterne overhovedet have Indfodsret, eller ikke, er der saa meget mindre Grund til nu at komme tilbage til, som selve de preussiske Domstole, saaledes som jeg i min Bog S. 10 flg. ved Citater af de paagældende Domme har dokumenteret, have underkjendt den preussiske Regjerings Nægtelse af, at Bestemmelsen om den for rlle Indfødte reserverede Indfødsret ogsaa omfattede Optanterne. I denne Opfattelse synes ogsaa den ærede Kritiker enig; thi det Spørgsmaal, der derefter ene er levnet som Drøftelsens Gjenstand, og som ogsaa alene beskæftiger den ærede Kritiker, er: Hvad forstaas ved le droit d'indigénat? Hvilket er Retsindholdet at dette Udtryk?

I min Bog $\mathrm{S} .17 \mathrm{flg}$. $\mathrm{S} .22 \mathrm{flg}$. har jeg besvaret dette Sporgsmaal derhen, at Indfodsret i det danske 
Monarki før som efter 1864 var og er enstydig med Statsborgerret, hvis fundamentale Indhold er en Ret til at være og forblive $i$ Landet, saa at derefter indfodte Slesvigere, selv om de have opteret dansk Undersaatsforhold, i Kraft af den dem ved Fredstraktat 30. Oktober 1864 Art. XIX 5te Stykke forbeholdte Indfodsret i Hertugdommerne (senere Preussen) nyde en Statsborgerret samme Steds eller en Hjemstedsret, ifolge livilken de ikke kunne udvises derfra, og at folgelig enhver Udvisning af en for 16. Novbr. 1864 indfødt dansk Optant i Hertugdømmerne er en flagrant Krænkelse af disse indfødte Optanters traktatmæssige og lovhjemlede Ret.

Hvad indvender saa min ærede Kritiker imod denne Paastands Rigtighed?

Han henviser forst til det formentlig ganske uantagelige Resultat i politisk Henseende, som vilde fremkomme ved denne Fortolkning, hvorefter de paagældende daıske Optanter skulde have bevaret deres statsborgerlige Rettigheder med alle dertil knyttede Virkninger i Hertugdømmerne (senere Preussen) samtidig med, at de vare fritagne for alle undersaatlige Pligter, særlig Værnepligten, i Hertugdømmerne (senere Preussen).

Ved Omtalen af dette Resultats formentlige Uantagelighed fra et politisk Synspunkt indskyder Forfatteren dog selv straks paa Stedet den Kjendsgjerning, at det, som jeg ved Anforslen af en Række danske Domme i min Bog S. 61 flg. har dokumenteret, er anerkjendt i den danske Retspraxis, idet de i Hertugdømmerne før 16. Novbr. 1864 indfødte Under- 
saatter ere anerkjendte som danske Statsborgere og derfor ikke kunne udvises fra Danmark uden alt Hensyn til, om de maatte have valgt at være preussiske eller danske Undersaatter.

"Men“, tilføjer den ærede Kritiker saa, "den politiske Virkning er dog, som jeg ikke behøver at udvikle nærmere, helt forskjellig for de danske Optanters Vedkommende."

Her har den ærede Kritiker dog taget sig Sagen for let; den nærmere Udvikling, som han ikke har indladt sig paa, maatte have fort ham til en ganske modsat Opfattelse. Sporgsmaalet om de danske Optanters Retsstilling ifolge min Forstaaelse af Fredstraktatens Art. XIX 5te Stykke bor nemlig besvares med Henblik paa den ved Fredsslutningens Tid henholdsvis $\mathrm{i}$ Hertugdømmerne og $\mathrm{i}$ Kongeriget Danmark bestaaende Retstilstand. Men derefter var Virkningen af den paagældende Bestemmelse aldeles ens baade $i$ Hertugdømmerne og i Kongeriget og i intet Tilfælde uantagelig. Forholdet var nemlig det, at de paagældende Indfodte, der ved Option af dansk Undersaatsforhold vare loste fra Undersaatsforholdet til Hertugdommerne, dog, naar de bevarede eller senere paany erhvervede Bopæl i Hertugdømmerne, vedblivende vare eller igjen bleve Undersaatter samıme Steds i Kraft af selve Bopælen, og, som bosatte Undersaatter, vare undergivne alle undersaatlige Pligter, endog Værnepligten. Paa ganske tilsvarende Vis stillede Forholdet sig omvendt i Henseende til de Indfodte i Danmark, der havde valgt at være Undersaatter i Hertugdømmerne. Med denne Retstilstand for Øje kontraherede 
selvfolgelig de Magter, der vedtoge Fredstraktaten 30. Oktbr. 1864 Art. XIX, nemlig den danske Konge som den hidtilværende Regent og Kejseren af Østerrig og Kongen af Preussen som „den nye Regjering i Hertugdommerne", og som Følge af bemeldte Retstilstand var der ingensomhelst abnorm Virkning knyttet til Bestemmelsen om, at Indfødsretten i den af mig hævdede Forstand henholdsvis i Hertugdømmerne og i Kongeriget kunde bevares selv for de Indfødte, der valgte at være Undersaatter henholdsvis $\mathrm{i}$ Kongeriget og $\mathbf{i}$ Hertugdømmerne.

Det er derfor, henset til det politiske Resultat ifolge den i Kongeriget og i Hertugdommerne i Aaret 1864 bestaaende Retstilstand, en i Luften svævende Paastand, som den ærede Kritiker fremsætter S. 233, at det indtil videre ikke kan anses for godtgjort, at de tyske Regjeringer med klart Blik skulde have hidfort saadanne politiske Begivenheder, som de foran af ham udviklede.

Selvfolgelig kan saa denne traktatmæssig sikrede Retsstilling for de danske Optanter i Hertugdømmerne ikke i nogen Maade ændres eller mindskes ved Hertugdemmernes efterfølgende Indlemmelse i Preussen; thi Preussen har kun erhvervet Hertugdømmerne med Forpligtelsen til at respektere den ved Fredstraktaten 30. Oktbr. 1864 Art. XIX 5te Stykke stiftede Ret for Optanter uden alt Hensyn til, om denne ifolge preussisk Lovgivning maatte medføre Ulemper, som den ikke medforte ifolge den paa Afstaaelsens Tid i Hertugdonımerne saavel som i Kongeriget Danmark gjældende Ret. 
J'g tillader mig her i Forbigaaende at henlede min ærede Kritikers Opmærksomhed paa, at hele denne Udvikling alt staar at læse i min Bog S. 58 flg., hvor jeg har gjendrevet den tilsvarende af den preussiske Regjeringskommissær i Landdagen fremsatte Paastand, som nu, uden alt Hensyn til min Gjendrivelse, er gjentaget af den wrede Kritiker.

Saalænge den her omtalte, alt i min Bog fremsatte Bevisforelse ikke er gjendrevet, maa jeg derfor havde, at den politiske Virkning af den af de danske Domstole godkjendte Fortolkning af Fredstraktatens Art. XIX 5te Stykke paa ingensomhelst Maade kan paaberaabes mod dens Rigtighed.

Fra denne forste Indvending, som min ærede Kritiker fremforer, gaar jeg saa videre til at omtale den næste.

„Det maa“, siger han, „i en fortrinlig Grad komme an paa, hvad de kontraherende Magter egentlig have tænkt sig, da de optoge Bestemmelsen om Indfødsrettens Bevarelse i Fredstraktaten“; "og“, tilføjer han, „allerede efter mindre end et Tiaars Forløb rar deres Forstaaelse deraf modstridende. Den, som vil afgjore Fortolkningssporgsmaalet paa en overbevisende Maade, maa derfor medtage og fuldt udnytte Aktstykkerne, ogsaa de forberedende, ved Fredsforhandlingerne i 1864, i Særdeleshed dem fra dansk Side, der havde foranlediget Optagelsen af det paagjældende Afsnit; men ogsaa den anden Parts. Forfatteren gjør ikke dette og angiver ikke, om muligvis dette Materiale er gjort tilgjængeligt paa et andet Sted, eller hvorfor det ikke har staaet til hans Raadighed." 
I Begyndelsen af sine Bemærkninger fremhæver den ærede Kritiker, at han i Særdeleshed har interesseret sig for den statsretlige og retshistoriske Methode, som jeg har fulgt ved mit Arbejde. De ovenanførte Bemærkninger kunne da nærmest tydes som en Kritik af min formentlig ikke tilstrækkelig grundige Metode.

Jeg skal hertil bemærke, at jeg ved retlige Aktstykkers Fortolkning først og fremmest holder mig til Ordene som Udtryk for Tanken, idet jeg gaar ud fra, at Parterne have ment, hvad de have sagt. Kun hris Ordene i og for sig maatte være tvivlsomme eller nogen af Parterne maatte paastaa, at Meningen har været end anden, end Ordene hjemle, kunne Oplysninger, hentede fra Kjendsgjerninger, der ligge udenfor selve Texten, faa Betydning. Men dette har jeg nu ikke fundet at være Tilfældet med Fredstraktatens Art. XIX 5te Stykke. Derfor har jeg ikke givet videre Meddelelser angaaende de mig tilgjængelige Forarbejder til nærnte Bestemmelse, end i min Bog S. 6, 49 og 67 anfort. Men naar nu den ærede Kritiker bebrejder mig, at jeg ikke har givet yderligere Oplysninger om Forarbejderne, skal jeg ikke undlade at gjore udførligere Rede for, hvad jeg her har kunnet finde desangaaende.

Det første Udkast til Art. XIX, som blev forelagt dè danske Befuldmægtigede, har jeg ikke kunnet finde; men det kan ses af det andet, som omtales straks nedenfor, paa Navnene nær at have været ens- 
lydende med den tilsvarende Artikel XII i Züricher Freden 1):

I den Instrux, som tilsendtes de danske Befuldmægtigede dat. Kjabenhavn den 30te August 1864 hedder det saa:

"Ved Fjendens Overmagt og Omstændighedernes Tryk har Kongen set sig nødsaget til at opgive sine Rettigheder til den storste Del af Monarkiets Lande og Provinser Syd for Kongeaaen; men Hans Majestet, har ikke opgivet sin Ombu og Interesse for disse Landsdeles Bebnere, over livilke han var kaldet til at herske. Ligesom de kongelige Befuldmægtigede derfor i det Hele under Forhandlingerne altid ville berare $\mathbf{i}$

1) Les sujets Lombardes domiciliés sur le territaire cédé, par le present traité, jouiront pendant l'espace d'un an a partir du jour de l'échange des ratifications et moyennaut une déclaration préalable à l'autorité compétente de la faculté pleine et entière d'exporter leurs biens-meubles en franchise de uroits et de se retirer avec leurs fumilles dans les États de Sit Majesté Impériale et Royale Apostolique, auquel cas la ynalité de sujets autrichiens leur sera maintenue. Ils seront linre's de conserver leurs immeubles sur le territoire de la Lomliardie.

La même faculté est accordée réciproquement aux individus originuires du territoire cédé de la Lombardie, établis dans les États de Sa Majesté l'Empereur d'Autriche.

Les Lombards, qui profitéront des présentes dispositions ne pourront être de fait de leur option, inquiétés de part ni d'autre, dans leurs personnes ou dans leurs propriétés, situées dans les États respectifs.

Le delai d'un as est étendu a deux ans pour les sujets originaires dn territoire cédé de la Lombardie qui a l'époque de l'échange des ratifications du présent traité se trouveront lors du territoire de la Monarchie autrichenne. Leur décluration pourra être reçue par la mission autrichienne la plus voisine ou par l'autorité supérieure d'une province quelconque de la Monarchie. 
Erindringen, at disse Landsdeles Vel ogsaa ligger og vedbliver at ligge Hs. Majestæt paa Hjertet, om de end gaar ind under et fremmed scepter, saaledes er der navnlig nogle Punkter, paa hrilke den kgl. Regjering særlig maa henlede Opmærksomheden."

Forst nævnes saa i Instruxen Omsorgen for Bevarelsen af de legislative og konstitutionelle Organer i Hertugdømmerne. Derefter fortsættes;

„Særlig onsker Hs. Majestæet dernæst at sikre den Del af Hertugdømmet Slesvigs Befolkning, der i Sprog og Nationalitet løører til Kongeriget. Dersom Kongen var vedbleven at regjere i Slesvig, vilde Hs. Majestæot ufrarigelig have fastholdt de tvende Nationaliteters Ligeberettigelse i dette Hertugdømme. Den samme Retfærdighed venter Hs. Majestæt, at de allierede Magter ville vise, og han maa insistere paa, at Fredstraktaten kommer til at indeholde den fornedne Garanti for, at de dansktalende Beboere af de afstaaede Territorier ville nyde den Beskyttelse for deres Sprog og deres nationale Ejendommeligheder, hvorpaa de have et uafviseligt Krav."

„Det er dernæst den kongelige Regjerings Anskuelse, at personlige og Ejendomsrettigheder, hvoraf Individerne alt ere i lovlig Besiddelse, ikke maa lide nogen Indskrænkning ved Freden. Denne Grundsætning finder navnlig Anvendelse paa

1) Indfodsretten. Herefter ville ultsua alle de Perwoner, som for Fredens Lnderte!ning have erheret Indfodsret $i$ Monurkiet, uden Hensyn til, i hilken Landsdel de ere fodte, nu befindes bosiddende eller fremtidig muatte rolge ut tuye Ophold, suacel i Kongeriget som i Hertugdommerne 
ogsta fremtidigt vedblive at nyde alle de Rettigheder, som paa ethrert Sted ere betingede af Indfodsret." Fra de danske Befuldmægtigede fulgte saa en Indberetning til den danske Regjering under 14de Septbr. 1864, med hvilken der som Bilag fulgte et Udkast til en Art. V, den nuværende Art. XIX.

Deri lød forste Stykke vedblivende som i Züricher Fredens Art. XII, dog at det ene Aar var forlænget til to.

I andet Stykke var indskudt Ordene „aux sujets Danois et" efter Ordet "réciproquement". Den tidligere alene hjemlede Optionsret af kongerigsk Undersaatsforhold for Undersaatterne fra de afstaaede Distrikter var derved udvidet til en Optionsret af hertugeligt Undersaatsforhold for kongerigske Undersaatter. Om Aarsagen til denne Udvidelse henviser jeg til de af den ene danske Befuldmægtigede givne Oplysninger, der omtales $\mathrm{i}$ min Bog S. 67. Men den tilsvarende Endring havde man endnu ikke faaet indfort i fjerde Stykke. Det var fremdeles redigeret paa den gamle Vis, kun at de to Aar nu vare blevne til tre og lød derfor paa: „Den toaarige Frist er forlænget til 3 Aar for de fra de afstaaede Territorier stammende Personer, som paa Fredstraktatens Ratifikationstid befinde sig udenfor Kongeriget Danmarks Territorium" o. s. v.

Den nurærende Art. XIX 5te Stykke fandtes endnu ikke i det andet Udkast.

Men i de danske Befuldmægtigedes ovennærnte Indberetning af 14. Sept. 1864 hed det saa angaaende 
det fremsendte Udkasts foromtalte Art. V, nuværende Art. XIX:

„Artikel $V$ have vi tilligere indsendt; men ved Artiklens nuværende Redaktion er Fristerne af $1 \mathrm{og}$ 2 Aar ifolge et af os allerede for længere Tid siden udtalt Onske forandrede til resp. 2 og 3 Aar. Vi have Grund til at tro, at en yderligere Forlængelse ikke vil mode synderlig Vanskelighed, ligesom ri heller ikike hare opyivet Habet om $i$ denne Artikel at fua optayet en Bestemmelse, hrovefter de, der nu ere i Besiddelse af Indfodsret i Monarkiet, fua denne deres Ret forbeholdt $\mathbf{i}$ sammes fulde Omfang efter den erentuelle Adskillelse of Hertuylommerne fra Kongeriget."

De Befuldmegrtigedes Haab er da gaaet i Opfyldelse, idet Bestemmelsen om Indlodsrettens Bevaring er indføjet som 5te Stykke' $i$ den endelige Affattelse af Fredstraktatens Art. XIX.

Disse Oplysninger har jeg kunnet indhente her, og det vil ses, at de i Et og Alt bekræfte, at den danske Regjerings Mening med den foreslaaede Tilfojelse i Et og Alt er i Overensstemelse med dens Ordlyd og med min Fortolkning af den.

Jeg har dernast ikke undladt i min Bog S. 6 og 49 at meddele, hvad jeg her har fundet om den preussiske Regjerings Forstaaelse af Art. XIX 5te Stykke, bestaaende $i$, at den $i$ en Note fra Aar 1867 hor udtalt, at derefter "tilsyneladende" de, som ikke udvandrede, skulde bevare "Statsborgerretten"; men denne Udtalelse er i og for sig helt ubestemt; jfr. Orlet „tilsyneladende"; og der tilfajes yderligere, at Droftelsen af Bestemmelsens Betydning maatte kunne forbeholdes, 
incltil et praktisk Tilfælde maatte give Anledning dertil. Den preussiske Regjering synes derfor endnu i 1867 slet ikke at have gjort sig selv Rede for Meningen med den. Saa meget mindre kan det forventes, at den alt skulde have været paa det rene dermed under Forhandlingerne derom i 1864. Den maa derfor sna. rere antages at $\nabla æ r e$ gaaet ind paa Vedtagelsen af Art. XIX 5te Stykke uden noget klart Begreb om Indholdet. Men det er selvfolgelig den preussiske Regjerings Fejl, hvis den liar gjort dette, og kan ikke i nogen Maade indvirke paa Bestemmelsens bindende Kraft overensstemmende med dens virkelige Indhold.

Havde det foreliggende Spørgsmaal været rent historisk, vilde jeg dog ikke lave undladt ogsaa at ansoge den preussiske Regjering om de Oplysninger, som den maatte sidde inde med. Men da Sporgsmaalet tillige er politisk, fandt jeg det illoyalt at ansoge den om Oplysninger, som eventuelt vare bestemte til at benyttes mod den selv. Det maa da blive den ierede Kritikers Sag eller andres, som have Adgang til de preussiske Arkiver, at hente Oplysning derfra; thi, som Kjendsgjerningerne foreligge, er det den preussiske Regjering, der maa fore Beviset, hvis den vil paastaa ikke blot, at de osterrigsk-preussiske Regjeringer selv have ment noget andet, end de have sagt i Art. XIX 5te Stykke, men ogsaa, hvąd det yderigere maatte komme an paa, hvis denne afvigende Mening skulde have nogen Betydning i retlig Henseende, at den dinskie Regjering hur ruret enig med dem $i$ at mene noget andet, end der er sayt $i$ bemeldte stykke. Saalænge saadant Bevis ikke er fort, og dct 
er endnu ikke sket, holder jeg mig til Artiklens Orllyd og fortolker dens Mening paa Grundlag deraf, saaledes som ogsaa baade de danske og de preussiske Domstole ses at have gjort, rigtignok for de sidstes Veclkommende med et Resultat, som jeg i min Bog har dokumenteret at være urigtigt.

Her møder jeg saa imidlertid den ærede Kritikers anden mod min Fortolknings Rigtighed fremforte Anke, at min Bevisforelse er ufyldestgjorende, fordi selve Textens rette Mening ikke er klar, da det er tvivlsomt, hvad der forstaas ved Udtrykket "le droit d'indigénat", og man følgelig ingenlunde med Sikkerhed kan lægge den Betydning ind deri, at Ordet skal være enstydigt med Statsborgerret, saaledes som af mig paastaaet.

Saa vender jeg da efter den ved min xrede Kritikers Anke over min statsretlige og retshistoriske Metode foranledigede Digression tilbage til det orenfor rejste Spørgsmaal, som altsaa bliver Undersogelsens Kjærne:

Hvad forstaas ved: "le droit d'indigénat" i Fredstraktatens Art. XIX 5te Stykke? Hvilket cr Retsindholdet af disse Udtryk?

Til Støtte for den Paastand, at Meningen med Ordet Indfodsret er tvivlsom, henviser den ærede Kritiker til, at "Indigenatets" Begreb i Almindelighed er saa sværende (schwankend), at den tyske Rigsforfatning har anset det for nodvendigt at forklare det ved en indgaaende Opregning af dets Kjendetegn.

Men her gjor min ærede Kritiker sig skyldig i en Forskydning baade af Tid og Rum, naar han betragter Spørysmaalet om Betydningen af Ordene „le droit 
d'indigénat", i Fredstraktatens Art. XIX 5te Stykke fra et unirerselt Synspunkt, i Kraft deraf tager sit Udgangspunkt fra Ordet Indigenat og paa den Maade endogsaa inddrager en Redegjorelse for, hvad Indigenat $\mathrm{i}$ den tyske Rigsforfatning 16. April 1871 Art. 3 betyder, i Undersøgelsen af, hvilken Meningen er med Ordene „le droit d'indigénat" i Fredstraktaten 30. Okt. 1864 Art. 5.

Jeg har allerede i min Bog S. 8 fremhævet, hvorledes selve Udtrykket "le droit d'indigénat" beviser, at vi her have at gjore med et for det danske MIonarki ejendommeligt Udtryk; thi udenfor Danmark taler man ikke om Indfødsret eller $\mathbf{j}$ fransk Oversættelse "le droit d'indigénat"; men, hvad netop den tyske Rigsforfatning Art. 3 frembyder Exempel paa, om Indigenat, indigénat."

Og hvad der saaledes allerede fremgaar af selve Udtrykket, bekræftes yderligere paa en aldeles afgjorende Maade ved selve Affattelsen af Art. XIX 5te Stykke, da den lyder paa, at Indfødsretten er bevaret - le droit d'indigénat est conservé - for alle de Personer, som ere i Besiddelse af den paa det Tidspunkt, da Fredstraktatens Ratifikation foregaar, altsaa den 16de Novbr. 1864. Der kan nu ikke være Tale om at bevare anden Indfodsret end den, hvoraf de paagjældende Personer alt forinden den 16de Novbr. 1864 vare i Besiddelse, og denne Indfødsret var ingen anden end den tidligere $i$ det danske Monarki anerkjendte og bestaaende Indfødsret. Denne samme Ret skulle de, som vare i Besiddelse af den i det tidligere samlede danske Monarki, fremtidig bevare i begge de 
fremtidig adskilte Bestanddele af Monarkiet, baade $\mathbf{i}$ Hertugdømmerne og i Kongeriget, og samme Indfødsret skal $\mathrm{i}$ begge de paagjaldende Dele være forbeholdt for wlle dem, som paa det anforte Tidspuukt vare $\mathbf{i}$ Besiddelse af den, altsaa uden Hensyn til det forud omtalte Valg af Undersaatsforhold henholdsris $i$ den ene eller $\mathrm{i}$ den anden Del.

Saa ere vi altsaa forelobig naaede til Tished om, at den Indfødsret, hvorom Fredstraktaten Art. XIX 5te Stykke handler, er den i det danske Monarki den 16de November 1864 anerkjendte Indfodsret eller Indigenatret, og saa spørge vi videre: Hvilket var da Indholdet af denne Indfodsret eller Indigenatret?

Den ærede Kritiker mener saa, at man ved Begrebet Indfødsret i den danske Statsret kan tanke paa muligvis ganske forskjellige Ting,

enten og nærmest paa de materielle Retsforhold, lvilke "Patentet" af 15. Jan. 1776, som det synes ham, alene vilue ordne og har ordnet, for hvis Skyld den forste Gang nojere regulerer det ogsaa tidligere ikke ukjendte formelle Begreb om Egenskaben som Indfodt;

eller ogsaa paa de materielle Retsforhold, hvis Ordning ved en senere udfyldende Fortolkning fra de højeste Forvaltnings- og Dommermyndigheders Side tillige kan være anset som sket ved „Patentet" 1776 ;

eller endelig paa det hele Indbegreb af materielle Retsforhold, for hvis Virkning det i "Patentet" af 1776 fastsatte formelle Retsbegreb af Egenskaben som Indfodt 1864 var afgjørende, og som ifølge 
Matzen tilsammentagne udgjorde Statsborgerretten.

Den ærede Kritikers Konklusion af disse Præmisser er da den, at det ikke kan anses som bevist, at Fredstraktaten 1864 har havt noget andet for Øje end det efter hans Opfattelse meget beskedne Indhold af Forordningen af 1776.

Paa denne Udvikling er mit Svar det, at den i sine Præmisser som i sine Konklusioner er urigtig. Der gaves $\mathrm{i}$ det danske Monarkis Statsret kun en Betydning af Ordet Indfødsret eller Indigenatrecht, hvilke Udtryk Fredstraktaten paa Fransk gjengiver med Ordet "le droit d'indigénat", og denne Betydning er netop den $\mathrm{i}$ min Bog udviklede og dokumenterede.

Den ærede Kritikers Bevisførelse lider nemlig først af den Grundfejl, at den svæver i Luften; idet den begynder med en blot og bar Hypotese ${ }^{\jmath}$ ), der senere, man ved ikke paa hvilken Maade, bliver til en Kjendsgjerning, paa hvilken hele Bevisførelsen bygges, og denne Hypotese er belt og holdent urigtig.

Hrorpaa bygges nemlig denne Hypotese om, at de kontraherende Magter ved Udtrykket „le droit d'ingénat" kun skulde have bavt de i Frdg. 15de Januar 1776 indeholdte Rettigheder for Øje? Den ærede Kritiker anforer til Støtte derfor, at det bestemte Udtryk „le droit d'indigénat" synes at pege hen paa den saaledes benævnte Forordning 15. Januar 1776 og paa den alene. De tilsvarende danske og tyske Udtryk Indfødsret og Indigenatrecht findes nu vel i den an-

1) Jfr. S. 231: Nimmt man aber an o. s. v. 
forte Forordnings Overskrift som Benævnelser paa selve Forordningen; men i denne Betydning af en Forordning er jo Udtrykket "le droit d'indigénat" i hvert Fald ikke brugt i Fredstraktatens Art. XIX 5te Stykke. Der staar det som en Betegnelse af en vis personlig Ret, naar det hedder, at alle de, som have „le droit d'indigénat", have bevaret den. Derom maa man da heldigvis være enig.

Men i denne i Fredstraktatens Art. XIX 5te Stykke givne Betydring af en personlig Ret forekommer nu Udtrykket Indigenatrecht aldeles ikke $i$ den tyske Text af Forordningen 15. Januar 1776 Art. 2-9; men der tales deri kun om Indfodte og Fremmede, som agtes lige med Indfølte, eller i $\S 7$ om „Auswärtige, die „gleicher Rechte mit den Eingeborenen fähig sind“. Derimod findes denne samme Vending i den tilsvarende danske Art. 7 netop gjengivet ved Sætningen: De Fremmede, som i Overensstemmelse med 2, 3, 4 og 5 Artikel kunne vente sig Indfødsret. Naar altsaa det til „le droit d'indigénat" svarende tyske Udtryk „das Indigenatrecht" i den i Fredstraktatens Art. XIX 5te Stykke girne Betydning end ikke nævnes i Indfødsretten 15. Jan. 1776, saa er dette allerede en Kjendsgjerning, som taler imod, at Fredstraktaten ved Brugen af de anforte Udtryk netop og alene derved skulde have havt Indfødsretten 15. Jan. 1776 for Øje. Derimod viser den danske Texts Benyttelse af Ordet Indfødsret, jævnført med den tilsvarende Omskrivning af Meningen med samme $i$ den tyske Text, paa en klar og utvetydig Maade, hvorledes Udtrykket Indfødsret og dets senere tyske Gjengivelse ved Indigenatrecht ere 
fremkomne, og hrad der forstaas ved dem, hvor de staa som en Betegnelse for en personlig Ret.

Til Bevis derpaa begynder jeg med en Omtale af selve de Indfodte. Disse Personer var der allerede for Frdg. 15de Jan. 1776 saavelsom ved selve denne Forordning $\mathrm{og}$ ved den efterfølgende Lovgivning indtil 1864 tillagt et vist Indbegreb af Rettigheder, som tilkom dem fremfor-Ikke-Indfodte. Men nu skete det, at Statsmagtens Indehaver fandt, at der efter Omstændighederne ogsaa var Anledning til at indromme andre ikke fra Fødslen af men ved efterfolgende Begivenheder til Landet knyttede Personer samme Retsstilling, som de Indfødte nod.

Hvorjedes skulde dette saa ske? Det kunde ikke ske ved simpelthen at erklære dem for Indfodte; det kunde selv den enevældige Konge ikke gjøre uden at komme i Strid med Kjendsgjerningerne. Og det var jo heller ikke paa selve den faktiske Egenskab som Indfødt, hvorpaa Vægten lagdes, men kun derpaa, at de paagjældende Ikke-Indfolte skulde nyde samme Retsstilling som Indfødte. Derfor tales der i Frdg. 15de Jan. $1776 \S \S 29$ helt igjennem om dem, som agtes lige med Indfødte og i Modsætning dertil om Udlændinge, som ikke agtes lige med dem. Men denne Udtryksmaade fojede et besværligt Paahæng til Ordet Indfødt, som man let var udsat for at glemme, hror det skulde være tilføjet. Dette er allerede sket i selve Forordningen 15de Jan. $1776 \S 1$, hvor der kun tales om Born af indfødte Undersaatter, skjønt der aabenbart burde være tilføjet: eller af dem, som dermed lige agtes. Men til Nød kurde denne Udtryksmaade endda 
passere, saalænge der kun var Tale om en enkelt Forordning og de deri indeholdte enkelte Forskrifter vedrørende Indfødte. Derimod blev den mere og mere besværlig, efter som Lovgivningens Bestemmelser om Indfødtes i Modsætning til Fremmedes Retsstilling bleve mere og mere omfattende. Saa maatte man have et enkelt omfattende Udtryk for den Retsstilling, som de Indfødte nød, og som ved Naturalisation blev Udlændinge til Del. Det fandt man nu netop i det allerede $\mathrm{i}$ Indfødsrettens danske Text Art 7 benyttede Udtryk Indfødsret; jfr. f. Ex. Reglement for Kongens Livjægerkorps 22de April 1829 § 5, som taler om, at den, der antages $\mathbf{i}$ dette Korps, enten maa være født $\mathbf{i}$ Kongens Lande eller være "benaadet med Indfødsret". Derfor fremkommer dette Udtryk i Forfatningslove, der bestemme, hvorledes Udlændinge kunne erhverve Indfødsret, f. Ex. i Forfatningslov for det danske Monarkis Fællesanliggender 2den Okt. 1855 § 47, hvor den tyske Text dog undtagelsesvis alene har Udtrykket Indigenat; jfr. derimod foreløbig Valglov s. D. §§ 1 og 7, hvori Indfødsret gjengives ved Indigenatrecht; og ved Siden deraf ogsaa i Love for de enkelte Landsdele, f. Ex. Danmarks Riges Grundlov 5. Juni 1849 § 35, der betinger Valgret til Folketinget af Indfødsret, og Forfatningslove for Hertugdommet Slesvig 15. Febr. 1854 Art. 19, $1^{0}$ og for Holsten 11. Juni $1854 \S 19,1^{\circ}$, der betinge Valgret til Stænderforsamlingerne af, at vedkommende Mand har Indfødsret eller Indigenatrecht eller dog uafbrudt i 10 Aar har opholdt sig i Kongens Lande. Det er da givet, at ved disse Udtryk Indfødsret og Indigenatrecht ikke alene forstaas de Rettigheder, som omhandles i Frdg. 
15de Jan. 1776, til hvilke saa de paagjældende Love skulde foje et positivt udenfor Indigenatretten selv faldende Tillæg; men Udtrykket er en Ramme, der betegner den Retsstilling, som ifølge den til enhver Tid gjældende Lovgivning maatte tilkomme de Indfødte i Modsætning til Fremmede, og denne Ramme udvides ved hver enkelt Lov, , der træffer nye Bestemmelser i Henseende til de Indfodtes særlige Retsstilling, saaledes at Udtrykkets Indhold derved udvides. Naar Lovbestemmelserne ere formulerede derhen, at Vedkommende skal have Indfødsret eller Indigenatrecht i Stedet for, at han skal være indfødt eller eingeboren, er dette stet, fordi det mere omfattende Udtryk Indigenatret netop og alene er det korrekte, da det omfatter ikke blot dem, der ved selve Fødselen have erhvervet Egenskaben som Indfodte og den dermed folgende Retsstilling; men alle dem, som paa enhversomhelst Maade ifølge den til enhversomhelst Tid gjældende Lovgivning maatte have erhvervet den Indfodte tillagte Retsstilling.

Denne Betydning af Indfødsret eller Indigenatret er derfor den eneste, overalt $i$ det danske Monarki indtil 1864 gjældende, og en tilsvarende kan derfor ogsaa alene tillægges Ordene "le droit d'indigénat" $i$ Fredstraktatens Art. XIX 5te Stykke; thi de ere den nojagtige franske Gjengivelse af de tilsvarende danske og tyske Udtryk, hvorfor ogsaa den officielle henholdsvis danske og tyske Gjengivelse af Fredstraktatens Text gjengiver dem ved Indfødsret og Indigenatrecht. Den anforte Betydning maa baade Kongen af Danmark som hidtilværende Regent i Hertugdømmerne og 
Kejseren af Østerrig og Kongen af Preussen som Hertugdømmernes "nye Regjering" have lagt til Grund for Ordets Forstaaelse, hvor Talen er om at bevare Indfødsretten i Kongeriget og i Hertugdommerne. At de skulde have villet lægge en anden mindre omfattende Betydning ind $\mathrm{i}$ Ordet, kan for det forste ikke formodes, fordi Undtagelsen netop var til Fordel for begge Parters Undersaatter, og kan dernæst ikke med nogen Slags Føje paastaas, fordi den Magt, som vilde have lagt en anden end den almindelige legale Betydning ind $\mathrm{i}$ Ordet, maatte have taget udtrykkelig Forbehold i saa Henseende, hvilket ikke er sket.

At Ordet Indfødsret i Art. XIX. 5te Stykke ikke kan have anden, end den her ombandlede Betydning, kan den ærede Kritiker dernæst ogsaa overbevise sig om ad en anden Vej.

Hvilken var nemlig i 1864 de i Hertugdømmerne indfodte Personers Retsstilling? Aldeles vimodsigeligt den, at de nøde alle de ved den gjældende Lovgivning Indfødte i Hertugdømmerne tillagte Rettigheder, ikke blot dem, som vare hjemlede ved Forordningen 15de Jan. 1776, men ogsaa dem, som hjemledes ved hele den efterfolgende Luovgivning lige indtil 1864, selvfolgelig forudsat, at de fyldestgjorde de Betingelser, som de paagjældende Rettigheders Uovelse iovrigt krævede.

Dette er altsaa for de i Hertugdømmerne indfødte Personers Vedkommende Betydningen af, at Indfødsrettèn er bevaret for dem. Men da nu et og samme Udtryk, hvor ingen særlig Indskrænkning er gjort, ogsaa maa have et og samme Indhold og Betydning 
med Hensyn til alle de Personer, som det angaar og omfatter, og da nu Art. XIX 5te Stykke bruger en og samme Betegnelse for den Ret, som det tillægger alle de $\mathrm{i}$ samme omhandlede Personer uden at gjore nogensomhelst Sondring mellem dem, saa maa med logisk Nødvendighed ogsaa den alle de paagjældende Personer under Et tillagte Ret have et og samme Indhold.

Den iøvrigt aldeles uhjemlede Indskrænkning i Indfodsrettens Virkninger, som ogsaa enkelte danske Forfattere have villet opstille særlig for de naturaliserede Personers Vedkommende, er derfor under alle Omstændigheder uden Betydning med Hensyn til Fredstraktatens Art. XIX 5te Stykke, hvor der ikke særlig er Tale om naturaliserede, men horedsagelig netop kun om Indfodte.

At den her hævdede Betydning af Ordene "le droit d'indigénat" ogsaa er i fuld Overensstemmelse med de Oplysninger, som udenfor selve Traktatens Ordlyd foreligge om Foralagsstillerens, den danske Regjerings, Mening med Tilfojelsen af Fredstraktatens Art. XIX 5te Stykke vil uimodsigeligt fremgaa af den ovenfor S. 119. meddelte Instrux fra den danske Regjering til sine Befuldmægtigede ved Fredsunderhandlingerne og disses til den danske Regjering afgivne Beretning. Der er deri ikke med en eneste Stavelse hentydet til Frdg. 15de Januar 1776, og derfor heller ikke den fjerneste Hjemmel til at paastaa, at den danske Regjering ved Bestemmelsen om Indfødsrettens Bevarelse kun skulde have villet sikre de paagjældende Personer de i Forordning 15. Januar 1776 specielt fremhævede ,beskedne"6 
Rettighedor. De citerede Udtalelser vise derimod ligesaa uimodsigeligt, at den danske Regjering derved netop har villet sikre de paagjældende Personer den hele ifølge den $\mathrm{i}$ det danske Monarkis vedkommende Bestanddele gjældende Lovgivning Indfødte tilkommende Retsstilling, og den eneste Oplysning, som foreligger angaaende den preussiske Regjerings Forstaaelse af Ordene "le droit d'indigénat" $i$ den ovfr. $S .121$ omtalte Note viser da netop ogsaa, at den selv har forstaaet Ordene som enstydige med Statsborgerret.

Indfodsrettens Indhold er da i Fredstraktaten Art. XIX 5te Stykke den samme, som overalt ellers ifølge. det danske Monarkis Statsret, og den medfører der som overalt ellers en Statsborgerret, hris fundamentale Indhold er Retten til at være og blive i Landet og til, efter at være udvandret, frit at vende tilbage til det. Endog den Forbrydelse af denne Ret, som ifølge den ældre Lovgirning kunde finde Sted som Straf, naar en Indfodt domtes til Landsforvisning, var alt en ruin Tid forinden 1864 med en enkelt Undtagelse ophæret indenfor hele det danske Monarkis Omraade.

Imod dette utvivlsomme Indhold af Indfodsretten eller Indigenatretten $\mathbf{i}$ det danske Monarki opponerer imidlertid den ærede Kritiker ud fra sit snævre Syn paa Indfødsrettens Betydning ifølge Fredstraktatens Art. XIX 5te Stykke som alene beroende paa Indholdet af Indfødsretten 15de Januar 1776, og afviser derfor Paaberaabelsen af senere Lovbestemmelser angaaende Indfødtes Retsstilling som utilladelig, hvor det gjælder Bestemmelsen af Indfødsrettens Indhold i den anforte Artikel. 
Jeg henholder mig herimod paa Forhaand til det lige foran forte Bevis for, hvor aldeles uhjemlet denne Indsnærring af Indfodsrettens Indhold er, hvorledes dette derimod maa bestemmes paa Grundlag af hele det Indbegreb af de i 1864 om Indfødtes Retsstilling i det danske Monarki, henholdsvis i Hertugdømmerne, gjældende Regler, der bjemle dem, som den ærede Kritiker udtrykker det, Statsborgerrettens hele Fylde. Men da den ærede Kritiker ved samme Lejlighed kommer ind paa Betragtningen om den nærnte Forordnings Tilblivelse, Indhold og Øjemed, skal jeg for Fuldstændigheds Skyld ikke undlade ngsaa at folge ham ind paa denne Undersøgelse og godtgjore, at han ikke har set rigtigt paa Indfødsretten 15de Jan. 1776, bedømt den fejlagtig baade i Henseende til Form og Indhold og navnlig ikke har havt Øje for, at den indeholder ulige mere, end han har lagt ind $i$ den, idet allerede den anerkjender de Indfodtes og dermed ligestilledes Ret som en Borgerret.

Ud fra den ærede Kritikers urigtige Forudsætning, at de kontraherende Magter i 1864 kun maatte have arbejdet med Indfodsrettens Begreb ifølge det i Indfodsretten 15de Jan. 1776 givne Indhold, sperger han da først, om de alene have arbejdet med det Indhold, som Frdg. 15de Jan. 1776 gav Begrebet eller ogsaa med de Rettigheder, hvis Nydelse allerede for 15de Jan. 1776 var knyttet til de samme eller lignende Forudsætninger, som Indfødsretten kræver. „At nu", bemærker han, „Forordningen 15de Jan. 1776 ved sin Uastedelse skulde have havt en udover Embeds-, Kloster- og Stiftsretten vækkende Hensigt og dertil sva- 
rende Indhold, kan hverken sluttes af dens Ordlyd eller af de bekjendte politiske Forhold ved dens Udstedelse, som have fremkaldt den. Det maa, hvis Forfatteren vil bevise det modsatte, derfor ogsaa betegnes som en Mangel, at han ikke udforlig meddeler Centralmyndighedernes Forbandlinger, som have forberedt Loven eller, hris de maatte foreligge, angiver, hvor de ere at finde. Uden dem vil han vanskelig overbevise om, at Statsborgerrettens Fylde, hrormed han identificerer Indfødsretten, har inspireret Lovgiverens Tanke“.

Jeg skal hertil forst bemærke, at de mig bekjendte endnu bevarede Forarbejder til Indfødsretten ${ }^{1}$ ) ikke indeholde nærmere Oplysninger om det heromhandlede Punkt. Men derfor er dog min Bevisforelse ikke ufuldstændig. Jeg henholder mig nemlig ogsaa her til selve Forordningens Text og fortolker den ud fra den Forudsætning, at Lovgiveren har ment det, som han har sagt. Hvis Ordenes Betydning dernæst maatte findes tvivlsom og tilstede en Slutning til forskjellige Meninger, gaar jeg endvidere ud fra, at Lovgiveren har havt en fornuftig Mening med det, han har sagt. Ifølge denne sidste Forudsætning kan det nu formentlig allerede paa Forhaand ikke have Formodningen for sig; at en Forordning, som vilde udstyre de Indfødte med et Indbegreb af nye Rettigheder, skulde have villet røve dem saadanne, der alt tidligere vare anerkjendte som tilkommende dem. Sporger man, hvilke disse rare, henviser jeg til Udtalelserne i min Bog $\mathrm{S}$. 15, som Forfatteren formodentlig ogsaa har havt for Øje, hvor

1) Dr. Aage Friis: Bernstorff og Guldberg S. 72. 
jeg har paavist, at man allerede forinden $1776 \mathrm{i}$ statsog folkeretlige Forhold havde undtaget Indfødte fra at udvises og udleveres, altsaa forsaavidt alt forinden 1776 havde tillagt dem statsborgerlige Rettigheder. Vil den ærede Kritiker imidlertid mod denne Formodning henvise til Sætningen om, at Formodningen dog snarere maa være for det mindre end for det mere, saa skal jeg herimod gjore gjældende, at der i dette Tilfælde dog ogsaa foreligger mere end en Formodning, idet denne positivt bekræftes ved selve Forordningens Ordlyd, son den ærede Kritiker ikke synes mig at have skjænket tilbørlig Opmærksomhed. Ganske vist er dens specielle Formaal det, som han fremhæver, at tillægge de Indfadte visse bestemte Forrettigheder; men red at træffe Bestemmelser derom udtaler den tillige en mere almindelig Sætning om de indfødsberettigedes Stilling, der netop afgiver Lovgiverens Motiv til at skjænke dem de paagjældende Forrettigheder, hvilke Udtalelser derfor aldeles afgjort høre med til Forordningens positive Indhold.

I Forordningens Indledning udtales det nemlig som en af Lovgiveren erkjendt Sandhed, at Fordelene i Staten bor falde $\mathrm{i}$ dens Borgeres Lod. Naar samme Forordning nu i sin efterfølgende dispositive Del tillægger de indfødsberettigede Personer bestemte Fordele i Staten, kan det fornuftigvis ikke forklares paa anden Maade, end ud fra den Erkjendelse hos Lovgiveren, at de indfodsberettigede Personer, hvem disse Fordele tillægges, netop ere Statens Borgere.

$\mathrm{Og}$ denne Slutnings Rigtighed bekræftes yderligere positivt, naar de samme indfødsberettigede Personer $\mathbf{i}$ 
selve Forordningen $\S 1$ benævnes: Danske, Norske og Holstenere, hvorved kun kan sigtes til en Betegnelse af deres politiske Nationalitet, som henhorende til det dansk-norsk-holstenske Folkesamfund eller som Borgere $i$ det dansk-norsk-holstenske Monarki, der som saadanne selvfølgelig ogsaa maa være i Besiddelse af en Borgerret. Med denne positive Anerkjendelse af de indfødsberettigede Personer som Borgere i Staten og deres dermed givne Borgerrettigheder stemmer ogsaa modsætningsvis den efterfølgende Bestemmelse i $\S 9$ vedrørende de ikke lige med Indfødte agtede Fremmede eller Udlændinge. De have som saadanne ingen anden Ret til at bo og nære sig i Staten end den, som Statsmagten maatte finde for godt at tillægge dem. I saa Henseende vilde nu Indfødsretten ikke medføre nogen Andring i den hidtil bestaaende Tilstand. Derfor hedder det udtrykkelig i $\S 9$, at de skulle have fuld Frihed til at bo og nære sig i Kongens Riger og Lande paa alle de Maader, som Kongens Love og Forordninger tillade og hidtil tilladt have, ligesom de skulle nyde al den Skyts og Agtelse, som enhver af en kristelig mild Regjering kan vente efter sin Stand. Hvorfor gives der nu kun de Fremmede, ikke de Indfødte slige Tilsagn? Selvfølgelig fordi disse i Kraft af selve deres Egenskab som Borgere i Staten ere selvskrevne til at nyde de paagjældende Rettigheder, da, som Forordningens Indledning udtrykkelig fremhæver, "Landets Børn bør nyde Landets Brød“, og Retten til at bo og nære sig i Landet følgelig tilkommer dem som saadanne, uden at der behøves noget derom udtrykkelig givet Tilsagn, og uden at de i Bestemmelsen med Hensyn til 
de Fremmede indeholdte Forbehold fandt Anvendelse paa dem.

Paa den Maade mener jeg at have bevist, at Indfødsrettens Ord baade udtrykkelig og stiltiende hjemle Anerkjendelsen af de indfødsberettigede Personers Borgerret.

Skulde nu imidlertid den ærede Kritiker desuagtet finde, at der er en Lakune i Bevisforelsen for Forordningens virkelige Indhold, saa skal jeg tillade mig yderligere at henvise til den Kjendsgjerning, at selve Udstedoren af Indfødsretten, Indehaveren af Lovgivningsmagten for det samlede danske Monarki, positivt har godkjendt den.

Under de mange og lange Krigstilstande i Begyndelsen af forrige Aarhundrede maatte der i nevtrale Lande, der, som Danmark, drev betydelig Søfart, drages særlig Omsorg for, at Undersaatternes Handelsskibe sikredes mod Opbringelse, og derved spillede baade Rederens og Skibsforerens Nationalitet en særlig Rolle. Derfor bestemte Frdg. 4de Maj 1803 om Skibsfart i Krigstider $\S 1$, at Ingen kunde faa Skibscertifikat, som ikke inden Fjendtlighedernes Udbrud havde været i Besiddelse af fuld Borgerrettighed enten i de kongelige eller i andre nevtrale Stater. Med Hensyn til Skibsførerne bestemtes i $\S 4$, at Ingen under en opkommen Krig maatte føre et med kongeligt Søpas forsynet Skib, som var født i nogen af de Magters Lande, som da vare i Krig begrebne, naar han ikke inden Fjendtlighedernes Udbrud havde vundet Borgerrettighed $i$ Kongens Riger og Lande. Her forudsættes altsaa, at der existerer et Begreb, Borgerrettig- 
hed i Kongens Riger og Lande, og at den kan erhverves af en Person, der er fodt i Udlandet. Men hvorledes dette skal kunne gaa for sig, siges ikke udtrykkelig i denne Forordning. Dette Savn afbjælpes imidlertid $i$ en senere Forordning fra den Tid, da Danmark selv var bleven krigsforende. Da tillodes det, at der i Mangel af den Orlogsflaade, som Englænderne havde røvet, udrustedes Kommisfarere eller Kapere til at bekjæmpe Fjenden til Søs, og saa bestemtes i det af Kongen baade for Kongeriget og Hertugdommerne udstedte Kaperreglement 28. Marts $1810 \S 1$, at Ingen i Kongens Riger og Lande maatte fare paa Commis eller udøve Kaperi, med mindre han dertil var forsynet med lovmæssigt Kaperbrev. Saadant Brev meddeltes da alene dem, som ned Fødsel eller Antagelse havde erheerret dansk Borgerret. Her siges altsaa udtrykkelig, hvorledes dansk Borgerret erhverves, og det sker netop ved de samme Kjendsgjerninger, ved hvilke ifølge Frdg. 15de Jan. 1776 Indfodsretten eller Indigenatretten erhrerres. Jeg kan ikke skjonne rettere, end at Lovgiveren selv ved denne Bestemmelse positivt har godkjendt min Forstaaelse af Indfødsrettens Text, som hjemlende de indfødsberettigede Personer Statsborgerret, og for denne selve Lovgiverens Godkjendelse deraf maa efter min Mening selv min ærede Kritiker bøje sig. Skulde nu den ærede Kritiker imidlertid spørge, hvorfor da Indfødsret-Forordningen ikke, som den tyske Rigsforfatning Art. 3, nærmere specificerer Indfødsrettens Virkninger, men alene fremhæver Adgangen til Embeder og Bestillinger samt til Stifter og Klostre som Forrettigheder for de Indfødte og med dem lige- 
stillede Udlændinger, og hvorledes disse Rettigheder kunne sættes i Forbindelse med Statsborgerretten, saa vil jeg dertil svare: Den almindelige Statsborgerret som saadan, nemlig Retten til at være og blive $\mathrm{i}$ og igjen vende tilbage til Landet, behøvede ikke udtrykkelig at fremhæves, den var givet med selve Betegnelsen af de paagjældende Personer som Statens Borgere og Landets Born; thi har Lovgiveren erklæret en Person for Borger, maa han derved ogsaa have tilkjendt ham Borgerret, ligesom "Landets Børn“ som saadanne ere hjemmehørende i Landet. Men derimod var Borgernes udelukkende Adgang til Embeder og Bestillinger i Staten en Ret, der ikke var givet i og med selve Statsborgerretten som saadan. Den maatte derfor forst positiv tillægges Borgerne. Og hvorfor man just valgte den Ret, er heller ikke saa uforstaaeligt. Forfatningen var den Gang et Enevælde, Styrelsen var et embedsmæssigt Statsstyre, og al den Mulighed for Deltagelse i Statsstyrelsen, som der den Gang kunde være Spørgsmaal om, aabnedes derfor alene gjennem Adgangen til Embeder og Bestillinger. Naar den blev forbeholdt de Indfødte, repræsenterede den derfor al den politiske Ret, der overhovedet under Datidens Forfatning kunde tildeles Borgerne. Derfor repræsenterede Indfødsretten ogsaa allerede i Datiden al Statsborgerrettens Fylde.

Denne politiske Ret kom nu i Almindelighed ikke de indfødte Kvinder tilgode, og for dog ogsaa at yde. dem et Gode har man saa forbeholdt dem Adgang til Stifter og Klostre, hvilken Adgang dog senere med tvivlsom Grund er fortolket derhen, at den kun skal 
komme de adelige og lige med dem priviligerede Damer tilgode.

Der bliver herefter en fornuftig Mening og Sammenhæng i Indfodsrettens hele Tankegang, dens Præmisser og dens Konklusion.

Imod den her forsvarede Opfattelse af Indfødsrettens Væsen og Virkning ifølge Frdg. 15de Jan. 1776 henviser saa den ærede Kritiker, Side 232 Note, til den modstaaende Opfattelse, der skal udtales i et formentligt officiøst tysk Skrift om Indfødsretten, der udkom 1779, fordi deri ikke noget betones saa kraftigt som det, at Egenskaben som indfødt var ganske betydningslos $\mathrm{i}$ Henseende til alle ikke udtrykkelig de Indfødte i Forordningen forbeholdte Rettigheder og Fordele, og at Fremmede i Danmark efter som for Forordningen havde samme Andel i de borgerlige Rettigheder, der den Gang i Videnskaben endnu ikke vare udsondrede fra de statsborgerlige, som de Indfodte. Men herved er at bemærke, at den nævnte Forfatter paa det anforte Sted S. 100 understreger Begræensningen i Indfødsrettens Virkning med særlig Omhu for Holstens vedvarende Forbindelse med Tyskland, der, efter hvad han udtrykkelig betoner, ikke i mindste Maade er bleven mindsket eller forstyrret ved Indfødsretten. Derfor gaar han saavidt, at han end ikke medtager Forskriften om Indfodtes udelukkende Adgang til Stifter og Klostre. Men paa den næste S. 101 fremhæver han den Spore, som Indfødsretten kan være for en fremmed Fabrikant, Kunstner og Manufakturist til at nedsætte sig i de kongelige Stater. Og da Loven i dette Tilfælde meddeler Borgerret og begunstiger Ma- 
nufakturer og Handel, vil den ogsaa fra denne Side betragtet være fordelagtig for Holsten.

Den ærede Kritiker bor derfor ikke undlade at udfylde Forfatterens Udtalelse S. 100 med den efterfolgende Udtalelse S. 101. Da han paa sidstnærnte Sted udtrykkelig tillægger dem, der agtes lige med Indfødte, en Borgerret, maa han vel ogsaa forudsættes at gaa ud fra, at samme Ret ifolge Forordningen er tillagt de Indfødte selv.

Men ere vi da herefter endelig naaede til Erkjendelsen af, at Indfodsretten 15de Jan. 1776 hjemler de Indfodte og med dem ligestillede Personer dansk Borgerret, saa ere vi dermed dog endnu langtfra naaede til Stridens Afslutning.

Efter den ærede Kritikers Mening er der nemlig ikke vundet videre ved Anerkjendelsen af de Indfødtes og dermed ligestilledes Ret som en Borgerret; thi fortsætter han:

„Det laa de daværende Regjeringer yderst fjernt for Alvor at tænke paa saadanne politiske Retigheder for Undersaatterne, og hvor de, som ogsaa i denne Forordning (Indfødsretten), legede med Yndlings-Udtryk i den daværende vestevropæiske Politik, som „Statens Borgere", der vilde, som bekjendt, den oplyste Absolutisme ved Hjælp af dette Skin holde den frygtede Kjendsgjerning, de krævede politiske Rettigheders Væsen, ret virksomt paa Afstand. Saalænge som Akterne fra hin Tid ikke bevise andet, er det for mig ikke sandsynligt, at Indigenats-Forordningen af 15de Jan. 1776 har havt noget andet Formaal eller noget andet Indhold, end indenfor de regjerende og 
priviligerede Klasser at fastsætte visse Begrænsninger for visse Fortrin for den enkelte (innerhalb der regierenden und bevorrechteten Klassen gewisse Vorziige für den Einzelnen an gewisse Schranken zu binden); men ikke at fastsætte Betingelserne for de politiske Rettigheder for hele Befolkningsmassen".

„Det bevingede Ord fra Slutningen af det 18de Aarhundrede, der gjaldt for Preussen, at den preussiske Stat endte ved Landraaderne, gjaldt ifolge dets Mening den Gang ikke mindre for alle den oplyste Absolutismes Stater. I Lighed med Art. III i vor Rigsforfatning vil Forordningen oprindelig ogsaa kun have været bestemt til at binde de hojeste Myndigheder paa en Maade, som i Øjeblikket var dem selv kjærkommen, men i Tidens Lob ogsaa kunde være egnet til at forebygge Strømkæntringer."

I Gjensvar paa denne Udvikling maa jeg tillade mig at fremhæve, at den ærede Kritiker har et ganske forkert Syn paa den Aand, i hvilken Indfodsretten 15de Jan. 1776 er udstedt. Det var ikke en liberal Aand, med hvilken Enevælden koketterede, men en national Aand, hvis Maal var et tilsvarende Styre ved Fremmedes Udelukkelse fra at kunne spille Herrer i Landet. Det kan den ærede Kritiker læse sig til hos enhver dansk Historiker.

Men i Kraft af dette Forordningens Udspring og Øjemed fastslog den netop Begrebet om Folket som en politisk Enhed, omfattende Indfodte og alle dermed ligestillede, Danske, Norske og Holstenere som „Landets Borgere". 
Naar Forfatteren saa insinuerer, at disse Udtryk i Lovgiverens Mund kun skulde være Ord uden Indhold, Skin uden Virkelighed, fordi "de statsborgerlige Rettigheder i Litteraturen den Gang endnu ikke vare adskilte fra de borgerlige", saa skal jeg ikke strides om Datidens litterære Opfattelse; thi den er ligegyldig, da det er en uimodsigelig Kjendsgjerning, paa hvilken det her kommer an, at den danske Statsret alt længe før 1776 havde anerkjendt sondringen mellem de statsborgerlige Rettigheder, som tilkom Indfødte og dermed ligestillede, idet de ikke kunde udvises eller udleveres, og de borgerlige Rettigheder, der ogsaa tilkom andre Landets Indbyggere. Dette har jeg dokumenteret i min Bog S. 15. Følgelig mangler heller ikke fra den historiske Udviklings Synspunkt Forudsætningen for, at Indfødsretten ikke talte hen i Vejret, naar den talte om Landets Borgere, men at den fuldt ud var sig bevidst, hvilken Meningen var med disse Ord, og hvilken Retsstilling de medforte for de paagjældende Personer.

Med Hensyn til den ærede Kritikers Bemærkninger om de preussiske Tilstande i det 18de Aarhundrede og disses Almengyldighed for alle Datidens absolutistiske Stater skal jeg kun fremhæve, at det dog ingenlunde gaar an at ligestille alle Landes Tilstande med de preussiske. Den danske Enevælde var saaledes grundlagt af Kongemagten, stottet til de borgerlige Stænder i fælles Kamp mod Adelen, og allerede i Kraft af dette sit Udspring havde den vedblivende et afgjort mere folkeligt Præg. Indfødsretsbestemmelsen angaaende Adgangen til Embeder og Bestillinger 
bavde derfor ogsaa Betydning for den menige Befolkning, hris Born i Danmark kunde naa og naaede frem til de højeste Stillinger i Staten, idet Adgang til akademisk Uddannelse $\mathbf{i}$ høj Grad var lettet for dem gjennem de rige Stipendier, hvormed f. Ex. Kjobenhavns Universitet var doteret.

Jævnforelsen af den tyske Rigsforfatning 16de April 1871 Art. 3 med den danske Indfødsret 15de Januar 1776 er mig dernæst helt uforstaaelig. S. 233 mener den ærede Kritiker nemlig, at den sidstes Indhold og Øjemed har ræret tilsvarende til den forstes; men lige forud har han S. 231 udtalt, at Rigsforfatningens Art. 3 allerede deri afviger fra den danske Indfødsret af 1776, at den kun hjemler Forpligtelser for de forbundne Regjeringer overfor hverandre indbyrdes, ikke begrunder Rettigheder for Borgerne imod Staten, hvilket sidste altsaa den danske Indfødsret maa forudsættes at gjøre, hvorved den ærede Kritiker selv er kommen for Skade at betegne de Indfødte og dermed ligestillede Personer som Borgere. Men S. 233 er altsaa denne Ulighed forsvunden og dermed ogsaa de Rettigheder, som Indfødsretten tidligere forudsættes at tillægge Landets Borgere. Nu er der kun Tale om de Pligter og Indskrænkninger, som den paalægger Statsmyndighederne, skjont disse netop kun ere simple Følger af de Rettigheder, som Indfødsretten tillægger Borgerne. Med denne Konstruktion staar det da ogsaa i naturligt Sammenhæng, at den ærede Kritiker Gang efter Gang betegner Indfødsretten som et "Patent".

$\mathrm{Nu}$ udstedtes der ganske vist den 22de Jan. 1776 et Patent angaaende Fuldbyrdelsen af den i Indføds- 
retten Art. 1 givne Forskrift om, at kun Indfødte maatte indstilles og udnævnes til Embeder og Bestillinger. Men det "Pạtent" var forskjelligt tra selve Indfødsretten 15de Januar 1776, der ikke blot kaldte sig en Lov, men endog en uforanderlig og uryggelig Grundlov, hvis Udstedelse skete med en Højtidelighed og hilstes med Ovationer ${ }^{1}$ ), der gav Gjenlyd helt ned til Altona, ligesom der prægedes en Medalje til Minde derom.

Efter den ærede Kritikers Mening udviklede „Patentet" sig imidlertid forst senere til en Lov, bestemt til at efterkommes af de menige Undersaatter, uden at det dog angives, hvorledes denne mærkelige Forvandling, som det vilde have været højst interessant at faa nærmere dokumenteret, er foregaaet. Men saa, altsaa efter at "Patentet" var bleven til "Lov", er den $æ$ rede Kritiker fra sin Side meget interesseret $\mathbf{i}$ at faa at vide, hvorledes Domstolones og Forvaltningsmyndighedernes Praxis ved deres Interpretation maatte have beriget "Patentet", hvilke Oplysninger maaske for Slesvigs og Holstens Vedkommende vilde være at finde i Schleswig-Holsteinische Anzeigen.

1) Joannes Guilelmus Franciscus a Krohne: Poema in legem Indigenatis a Christiano VII latam Hamburgi 1776. (B. W. Luxdorph): Eugenes Eugenetes vi legis d. 15. Jan. 1776 Hauniæ. Monument for Indfodsretten, bestaaende af Lovtaler og Højtideligheder ved samme. Samlet ved Holck, Kjøbenhavn 1776. C. C. Lous: Indfødsretten. En Eclogue. Kjøbenhavn 1776. Om Indfødsretten. I Anledning af Kongens Fødselsdag i Aaret 1776; udgivet af et Selskab. (T. Rothe): Om Indfødsretten. Kjøbenhavn 1777. (G. B. Schirach): Ueber das königlich dänische Indigenatrecht. Hamburg 1779. J J. Dusch: Rede von dem Geiste des Indigenatrechts. Altona $1777: \mathrm{m}$. Al. 
Her kommer vi altsaa til det andet Indhold, som Forfatteren, efter hvad der er omtalt ovenfor S. 125, mener at kunne tillægge Indfødsretten i dansk Ret, nemlig et udover selve de specielle Bestemmelser i Indfodsretten 15de Januar 1776 gaaende, gjennem usuel Fortolkning af den beriget, Indbold.

Hvad nu denne Paastand angaar, bemærker jeg først, at jeg ikke ser, hvorledes Domstolenes Praxis skulde kunne faa Betydning paa dette Punkt, og jeg kan ikke finde Domme desangaaende, heller ikke i Schleswig-Holsteinische Anzeigen. Endog forudsat, at Adgang til Stifter og Klostre efter Omstændighederne kunde være gjort gjældende ved Domstolene, har jeg i hvert Fald ikke fundet noget Exempel derpaa for 1864. Embeders og Bestillingers Besættelse havde Domstolene $\mathrm{i}$ hvert Fald ikke at blande sig i. Og det samme gjaldt om Haandhævelse af den almindelige Borgerret, hror Talen blev om Udvisning eller Udlevering. Medens Domstolene selvfølgelig dømte baade Indfødte og Udlændinge til Landsforvisning, hvor og saalænge denne var foreskreven som Straf for Forbrydelser, kunde Beskyttelse for de Indfodte mod Udlevering eller Udvisning af andre Aarsager ikke soges ved Domstolene. Derom fattedes Beslutning af de administrative Myndigheder. Disses Bestemmelser i saa Henseende kunne saaledes vel have Interesse paa dette Punkt og vise da ogsaa, at Administrationen f. Ex. for Udvisnings Vedkommende vedblivende har fastholdt den Grundsætning, som allerede for Indfødsretten 1776 var anerkjendt f. Ex. ved en Forordning for Hertugdømmerne* af 1736; jfr. min Bog S. 15, at Indfodte og dermed 
ligestillede ikke kunde udvises. Dette fremgaar saaledes af Politibestemmelserne vedrorende Tiggere og Vagabonder i Samlingen af Forordninger saavel for Hertugdommerne som for Kongeriget. Jeg skal til Exempel derpaa knn henvise til et Cirkulære fra det $\mathrm{kgl}$. danske Kancelli 26de Januar 1819, der meddeltes det slesvig-holstenske-lauenborgske Kancelli ved Skr. 26de s. M. og en senere Skrivelse 26de Marts s. A. angaaende Forholdsregler mod omstrejfende Personer. Ere de indlændiske, skal der forholdes med dem efter Anordningerne, ere de udlændiske, skulle de erentuelt efter nærmere Undersegelse af deres Forhold udvises.

Spørger man saa, hvorpaa denne Sondring stottes, saa er Svaret, at der ikke anføres nogen Begrundelse, hrorfor Indlændinge ikke kunne udvises. Den Sæætning anses som givet red selve deres Eyenskab som Indlændinge, hvilket Ord er enstydiy med Indfødte, som det noksom fremgaar af selve den Modsætning, Indfødsretten opstiller mellem Indfødte og Fremmede og af de Love, der tildele Udlændinge Indfødsret.

Administrationen gaar altsaa her uden videre ud fra den selvsamme Forudsætning, som er udtalt i Indfødsretten 15de Januar 1776, at de Indfødte og med dem ligestillede Personer ere Statsborgere, der som saadanne ikke kunne udvises. Men da dens Afgjørelser ikke udtrykkelig støtte dette Resultat paa Indfødsretten 15de Januar 1776 og folgelig ikke kunne siges at indeholde en Fortolkning af denne, mener den ærede Kritiker altsaa formodentlig at kunne bortse fra deslige administrative Fastsættelser vedrørende Indfødte og dermed ligestillede Personer. Og dog bor de selv- 
folgelig medtages; thi de afgive utvivlsonme Vidnesbyrd om Administrationens Anerkjendelse af de Indfodtes og dermed ligestillede Personers Ret som saadanne eller af Indfodsrettens Egenskab som en Borgerret i fuldkommen Overensstemmelse med Udtalelserne i selve Indfodsretten 15de Januar 1776

Paa tilsvarende Maade stiller Forholdet sig red Sporgsmaalet om Udlevering. Begjæring fremsattes f. Ex. i 1834 fra den preussiske Regjering om at faa udleveret en Student Hoffbaner, fodt i Horsholm, til Domfældelse ved de preussiske Domstole for Deltagelse i politiske Demonstrationer. Men Kancelliet indstillede at nægte at efterkomme denne Begjæring, navnlig $\mathrm{i}$ Henhold til den Betragtning, at det er grundet $i$ en af alle menneskelige Begreber og menneskelige Indretninger uafhængig Nødvendighed, at man staar i et sierdeles retligt Forhold til det Sted og den Stat, hvormed man ved Fodselen er forbunden, og at dette Princip ligger til Grund for en Mængde traktatmæssige Bestemmplser, hvoriblandt findes de $\mathrm{i}$ min Bog S. 15 anforte Karteller, til hvilke Kancelliet henviser. IIen netop denne Nagtelse af Indfodtes og dermed ligestilleles Udlevering og det dermed stemmende Forbehold i Udleveringstraktaterne og Kartellerno indeholder ogsaa den ulovende Magts Anerkjendelse af Indfodsrettens Virkning som en Borgerret. $\mathrm{Og}$ den samme Retsvirkning af Indfødsretten fastholder dernæst ogsaa Lovgirningen, hvor der er Tale om Udvisning som efterfolgende administrativ Foranstaltning mod Forbrydere. Her rammer Udvisningen kun Udlændinge, som ikke have erhvervet Indfodsret, f. Ex. ifolge Frdg. 9de Juni 181 ? 
for Kongeriget, 25de Juni 1819 for Hertugdømmerne, i hvis $\S 1$ det hedder: „Er han (Forbryderen) en Udlænding, der ej har erhvervet Ret til at anses som hjemmehørende $\mathrm{i}$ vore Lande, da bor han, saasnart Straffetiden er udloben, forvises Landet for bestandigt ${ }^{\text {" }}$ o. S. V.

Alle de anførte administrative og legislative Bestemmelser og Afgjorelser ere derfor ligesaa mange talende Vidnesbyrd om, at det ikke var Mundsvejr, naar Statsherskeren ved Indfødsretten 15de Jan. 1776 erklærede Indfødte og dermed ligestillede Personer for Statens Borgere; men de vise trærtimod, at han ved alle sine efterfolgende Bestemmelser samvittighedsfuldt har respekteret deres Ret som saadanne, og disse Bestemmelser høre derfor med til, hver i sin Retning, at illustrere Betydningen af den i Indfodsretten 15de Jan. 1776 indeholdte almindelige Udtalelse om de paagjældende Personers Egenskab som Borgere. Derfor kan den ærede Kritiker ikke afvise disse og lignende Bestenmelser som saadanne, der ikke kunne tages i Betragtning ved Bestemmelsen af Indfødsrettens Indhold. De høre tværtimod med til fuldtud at dokumentere det historiske girne Begreb om denne, fra hvilket Fredstraktaten 30de Oktbr. 1864 Art. XIX gaar ud.

Og paa ganske samme Grund, paa hvilken det kgl. danske Kancelli byggede Nægtelsen af Indfødtes Udlevering, byggede det saa ogsaa, som Kancelli-Skr. 18de April 1835 viser, Anerkjendelsen af de expatrierede Indfødtes Ret til at vende tilbage til Fødelandet; og det slesvig-holstenske-lauenborgske Kancelli var fuldkommen enig i dette Resultat, som det udtrykkelig 
ses af Motiverne til Forslaget til Pl. 5te Novbr. 1841 for Hertugdømmerne, hvilke jeg har citeret i min Bog Side. 23. Denne Indfødsrettens Virkning, som alt forinden var anerkjendt for Kongerigets Vedkommende ved Pl. 1ste Maj 1810, jfr. min Bog S. 22, blev ogsaa for Hertugdommernes Vedkommende anerkjendt ved samme Pl. 5te Novbr. $1841 \S 1$, hvorefter der kun kræves Bosættelsestilladelse af Fremmede, ikke af Indfodte.

Det har derfor været og vil vedblivende være mig en uløst Gaade, med hvilken Hjenmel man, saaledes som man gjor i slesvig, har forlangt Bosættelsestilladelse for Personer, hvem Indfødsret er forbeholdt ved Fredstraktaten 30de Oktober 1864 Art. XIX 5te Stykke.

Endnu skal hertil kun fojes, at ligesom Indfødsretten under Enevælden medforte en udelukkende Adgang til Embeder og Bestillinger i Staten, saaledes medforte den efter Forfatningsforandringen Adgang til Udøvelse af politisk Valgret ifølge Forfatningslov 20de Oktbr. $1855 \S 27$; Danmarks Riges Grundlov 5te Juni $1846 \S 35$ og Forfatningslov for Slesvig 15de Februar $1854 \S 19,1^{\circ}$ samt for Holsten 11te Juni 1854 $\S 19,1^{\circ}$.

Jeg mener da $\mathrm{i}$ det foregaaende ligeoverfor den ærede Kritikers Indsigelser fyldestgjorende at have bevist :

At der ikke foreligger mindste Hjemmel for den Paastand, at de Magter, som redtog Fredstraktaten 30de Oktober 1864 Art. XIX 5te Stykke ved Udtrykkene "le droit d'indigénat" kun have havt de i Ind- 
fodsretten 15de Januar 1776 specielt omhandlede Rettigheder for $\varnothing \mathbf{j e}$;

at de anforte Ord paa det anforte Sted derimod maa forstaas $i$ deres almindelige legale Betydning som Udtryk for den Retsstilling, der i Henhold til den for 1864 henholdsris i Monarkiet, Kongeriget og Hertugdømmerne gjældende Ret tilkom Personer, der vare i Besiddelse af Indfødsret eller Indigenatret;

at Indholdet af denne Ret netop var en Statsborgerret, i Kraft af hvilken Indehaverne af den ikke kunde udvises, og som iovrigt indeholdt alle statsborgerlige Rettigheders Fylde, deriblandt i Særdeleshed ogsaa i ældre Tid Adyang til Embeder og Bestillinger, i nyere Tid politisk Valgret baade i Kongeriget og i Hertugdømmerne.

Hvad derimod angaar de Indfødtes og dermed ligestilledes nuværende Valgret i Preussen og i det tyske Rige, saa har jeg, som den ærede Kritiker med Føje fremhæver, ikke omtalt den, selvfølgelig af den formentlig fyldestgjorende Grund, at Besvarelsen af dette Sporgsmaal ikke afhænger alene af en Fortolkning af Fredstraktatens Art. XIX 5te Stykke; men der maa derved tillige tages Hensyn til Indholdet af de for Preussen og for Riget givne Valgretsbestemmelser, som det ikke har været min Opgave at granske. Jeg har kun havt til Hensigt at godtgjøre, at de Personer, hrem Indfodsret er forbeholdt ved Fredstraktatens Art. XIX 5te Stykke, i Kraft af den vare i Besiddelse af en Statsborgerret i Kongeriget saavel som i Hertugdemmerne, i Kraft af hvilken de ikke kunde udvises derfra, at denne Ret derfor ogsaa traktatmæssig er sikret dem i 
Preussen, i hvis Besiddelse Hertugdømmerne senere ere gaaede over, og at det derfor er en Krænkelse af deres traktatmæssige og lovlige Ret, naar den preussiske Regjering har udvist indfodte Optanter.

Naar endelig den ærede Kritiker spørger, hvilken Betydning Optionen og Reoptionen har under Forudsætning af den her hævdede Forstaaelse af Udtrykket Indfødsret, saa svarer jeg i Henhold til Traktatens ligefremme, utvivlsomme Ordlyd, at Optionen har den Betydning, at den, der opterer dansk Undersaatsforhold, selvfølgelig ikke $\mathbf{i}$ Hertugdømmerne kunde gjøre de Rettigheder gjældende, -der ikke, som f. Ex. Valgret til Stænderforsamlingen, alene vare betingede af Indfodsret, men ogsaa, som f. Ex. Adgangen til Embeder og Bestillinger, vare betingerle af, at den vedkommende rar indfødt Undersaat. Og Reoptionen havde da den modstaaende Betydning, at Optanter derigjennem gjenindtraadte i Nydelsen af de af Undersaatsforholdet betingede Rettigheder. Desangaaende henviser jeg til Frenstillingen i min Bog S. $40 \mathrm{flg}$.

Den ærede Kritiker gjor endnu til Slutning nogle Bemærkninger med særligt Hensyn til det sidste Afsnit af min Bog angaaende de Hjemløse. Han bemærker, at jeg ikke nærer Tvivl om, at Klagerne over stor Haardhed mod Optanter og Optantbørn maa rettes mod den preussiske Regjering, medens den ærede Kritiker mener, at Klagerne og Ønskerne om Afhjælpning maatte rettes helt andre Steder hen, hvorpaa der fortsættes med en Fremhævelse af alle Danskes, deriblandt ogsaa min egen, Uvidenhed om de politiske Foreteelser i Nordslesvig, spredte men mangfoldige, hver 
for sig lidet betydende, men samvirkende til et Hele. Han beklager derhos, at Materialet til Oplysning af dette Afsnit af den nyeste Historie, tildels rigtignok af uundgaaelige Aarsager, er saa overordentlig lidet tilgjængeligt for Offentligheden.

Hertil har jeg kun at svare, at jeg har dokumenteret min Frẹmstilling og lagt de Kjendsgjerninger, hrorpaa den bygges, offentlig frem; men Kjendsgjerninger ere haarde Halse, som man ikke faar Bugt med ved mystiske Antydninger om Ting, som maa holdes hemmelige.

Særlig vil han da ogsaa forklare det af nit Ubekjendtskab med den politiske Virkelighed, naar jeg efter hans Sigende i min Bog S. 86 har rettet en tungt vejende moralisk Bebrejdelse mod de preussiske Centralmyndigheder for deres Fremgangsmaade mod Personer, som havde iværksat en efter hans eget Sigende retlig ufuldstændig Option eller snarere vel en Skinoption, en Bebrejdelse, som, hvordan end Retsforholdet maatte stille sig, gjendrives blot ved et Blik paa de paagjældende talrige Personers Bevæggrunde, med Hensyn til hvilke der i Følge mine egne Meddelelser i min Bog S. 175 o. flg. aldeles ikke kan bestaa nogen Trivl.

Talen er her om den preussiske Kundgjorelse 12te April 1867, jfr. min Bog S. 85-86, hvorefter alle slesvigske værnepligtige Optanter skulde udvises, selv om de havde bevaret deres Bopæl i Slesvig.

Hvad jeg her har bebrejdet de 3 preussiske Ministerier, der i Forening have medvirket til Bekjendtgjorelsens Udstedelse, er imidlertid ikke Mangel paa Moral men Mangel paa Intelligens; thi mine ofte cite- 
rede Ord lyde: "Man ved ikke, om man skal le eller græde, naar man ser, hvorledes 3 forenede preussiske Ministeriers Intelligens munder ud i Udstedelsen af en Bekjendtgjørelse, der, som de preussiske Domstole selv have anerkjendt, indeholder et flagrant Retsbrud mod en Række preussiske Undersaatter". Da den ærede Kritiker selv betegner den paagjældende Option som en retlig ufuldstændig eller rettere som en Skinoption, saa skjenner jeg ikke rettere end, at den eneste retlig mulige Fremgangsmaade havde været den at erklære Optionen for ugyldig, saaledes som Overlandsretten i Kiel ogsaa senere har gjort, og vedblivende behandle de paagjældende Personer som preussiske Undersaatter; men i Stedet derfor at betragte Optionen som gyldig og derfor udvise de paagjældende Personer, er, endog bortset fra deres Indfødsret og dermed givne Borgerret, en Fremgangsmaade, som rober en afgjort Mangel paa Indsigt. Fra samme Synspunkt betragter jeg ogsaa den Side 175 i min Bog omtalte preussiske Note 20de Februar 1869, indeholdende Fyrst Bismarcks Erklæring om, at Udøvelsen af Optionsretten fra værnepligtige Personers Side var en Fremgangsmaade, hvorved de sogte at unddrage sig den preussiske Værnepligt, hvorfor de egentlig burde have været straffede, hvilket man kun af nabovenligt Hensyn til Dan mark undlod at gjøre.

Det ser virkelig ud, som om de preussiske Mjndigheders Intelligers rent ud sagt svigter, hvor Talen er om Fredstraktatens Art. XIX. Tildels forklares dette vel som Folge af, at danske statsretlige Udtryk, som Indf ødsret og Undersaatsforhold, fortolkes ud fra preus- 
sisk Opfattelse og derved misfortolkes. Af samme Aarsag kan forklares den urigtige Opfattelse af Betydningen af Option af Undersaatsforhold og Nægtelsen af Muligheden af en Reoption, angaaende hvilken sidste den ærede Kritiker selv fremhæver, at den embedsmæssige preussiske Opfattelse deraf synes at have været.vaklende; men mere uforklarligt er det, at de preussizke Myndigheder end ikke have kunnet faa Rede paa selve Optionsbetingelsernes virkelige Indhold, hvad de skiftende og indbyrdes modsigende Afgjorelser af de administrative og judicielle Myndigheder, ja endog af en og samme Domstol, noksom udvise. Og saa har man tilsidst ikke vidst anden Udvej end slet ikke at lade Spørgsnaalet afgjøres for Retten, men simpelthen lade Politiet udvise de paagjældende formentlige Optanter, i absolut Modstrid med Tilsagnet i Fredstraktatens Art. XVII. Naar saa Befolkningen ved de konstitutionelle og lovlige Midler, hvorover den raader, lægger sin berettigede Utilfredshed med den gyngende Retsgrund, hvorpaa den lever, for Dagen, saa udlægges denne dens Kamp for Retten som en statsfjendtlig Stræben, og saa faar den selv Skyld for, at Tilstandene forblive, som de ere, og ikke kunne ændres. Nen dette er, som jeg har fremhævet i min Bog, at lade Undersaatterne undgjælde for Regjeringens Brøde. Paa samme Maade vil ogsaa den ærede Kritiker, „hvorledes end Retsspørgsmaalet maatte stille sig“, fri Regjeringen, hvis nogen maatte anklage den, for at have handlet umoralsk ved Udvisningen af de værnepligtige Undersaatter, hvis Option var ugyldig, og som derfor vare vedblevne at være preussiske Undersaatter, idet 
han henviser til deres Bevæggrunde til at optere. Af hans Henvisning til S. $175 \mathrm{i} \min$ Bog ses det, at han sigter til dem, der opterede i Anledning af den fransktyske Krigs Udbrud, skjønt Bekjendtgjørelsen om de i Slesvig forblevne raernepligtige Optanters Udvisning alt var udstedt i April 1867, njedens Kंrigen med. Frankrig forst udbrod i Avgust 1870. Men selv med Hensyn til de $\mathrm{i}$ den Anledning opterende nordslesvigske Værnepligtige, skal jeg bemærke, at de ikke blot havde en udtrykkelig, traktatmæssig tilsikret Ret til at optere; men at der yderligere ved Pragerfredens Art. 5 var givet hele Befolkningen $\mathrm{i}$ de nordslesvigske Distrikter et Tilsagn om at blive gjenforenet med Danmark, hvis den red en fri Afstemning tilkjendegav sit Ønske derom, hvilket Tilsagns Optagelse i Pragerfreden vitterlig skyldtes Frankrigs Mellemkonst. Den preussiske Regjerings forholdsvis imødekommende Holdning under Forhandlingerne om Aabenraa-Konventionen vedrerende disse Optanter synes da ogsaa at vise, at den selv fandt Optionens Iværksættelse under de foreliggende Forhold mildest talt undskyldelig, idet den tillod de fleste af dem at vende tilbage og blive boende i Slesvig. Men hvorledes har den preussiske Regjering saa lonnet de Optanter, der vare forblerne i Slestig og dragne med i Krigen? I min Bog S. 69 læses et Exempel paa, at en saadan Optant, efter at have kjæmpet med Hæder i en Række blodige Slay under de preussiske Faner, tillige med Lørn og Bornebørn 30 Aar efter blev erklæret for Udlænding. Dette er en alt andet end moralsk Adfærd. Naar den ærede Kritiker finder det utaaleligt, at Landetş vaabendygtige Beboere ikke, 
naar det angribes, ere villige til at forsvare det, saa er det visselig ikke mindre utaaleligt, at Landet bagefter fornægter dem, der have vist sig rede til at ofre Liv og Blod for dets Forsvar. Naar til disse og andre Kjendsgjerninger komme saadanne fra den nyeste Tid, som at en preussisk Embedsmand offentlig er bleven sigtet for at have villet kjobe et Vidne til Brug i en Optantsag, uden at Sag er bleven rejst $i$ Anledning af denne Beskyldning, jfr. min Bog S. 136, saa tillader jeg mig at mene, at den preussiske Regjering i Henseende til sin Adfærd overfor Optanterne hverken har Moralen eller Retten paa sin Side. 